\title{
Outcome of non cardiac surgical patients admitted to a multidisciplinary Indian ICU
}

\author{
HG Pradeep Kumar ${ }^{1 *}$, MS Kalaiselvan ${ }^{1}$, MK Renuka², AS Arunkumar ${ }^{1}$ \\ From ESICM LIVES 2015 \\ Berlin, Germany. 3-7 October 2015
}

\section{Introduction}

Perioperative complications after non cardiac surgery are relatively frequent and potentially dangerous $[1,2]$. Data is also limited in these group of patient population in India. Hence we planned to study the profile of perioperative patients.

\section{Objective}

Study the clinical profile and outcome of perioperative patients admitted to a multidisciplinary ICU and identify risk factors if any for post operative mortality.

\section{Methods}

This is a prospective observational study on all perioperative patients admitted to a multidisciplinary ICU. The study was conducted between MAY 2014-NOV 2014. The primary outcome analyzed was perioperative complications and hospital mortality. The secondary outcome analyzed were duration of ICU stay, ventilator free days and ICU free days. We expressed results as mean \pm standard deviation, and frequencies for qualitative variables. We used the Fisher exact test and the Mann-Whitney's test with a significance level of 0.05 .

\section{Results}

This study included 185 patients of which $55 \%(\mathrm{n}=102)$ were male. Mean age was $49.8 \pm 18.3$ years, with $34 \%$ $(\mathrm{n}=63)$ above 65 years. Mean admission APACHE-II score was $11 \pm 6.38$ and SOFA score was $3.16 \pm 2$. The mean discharge SOFA score was $2.51 \pm 2.4 .60 \%(\mathrm{n}=109)$ of patients underwent elective surgery while $41 \%(n=76)$ had emergency surgery. The most common reason for post operative ICU admission was for elective mechanical ventilation in view of co-existing medical conditions

${ }^{1}$ Sri Ramachandra Medical College and Research Institute, Dept of Critical Care Medicine, Chennai, India

Full list of author information is available at the end of the article
$47 \%(\mathrm{n}=87)$. The mean duration of surgery was $171.6 \pm$ 97.8 mins. The most common surgical procedures were gastro-intestinal 30\% $(n=56)$ followed by orthopaedic $20.5 \%(n=38)$ and genito-urinary $16 \%(n=16 \%) .66 .5 \%$ $(\mathrm{n}=123)$ patients received a general anesthetic alone of whom $67 \%(n=83)$ required elective mechanical ventilation in ICU. The overall mortality was $7.6 \%(\mathrm{n}=14)$. Post operative surgical complications were seen in $2.2 \%$ $(n=4)$ and nonsurgical complications were seen in $14 \%$ $(n=26)$ patients of which AKI was most common 38.5\% $(n=10$ of 26). Secondary outcome measures were (Mean \pm SD) ICU LOS $3.05 \pm 2.1$ days, ICU free days6.28 \pm 3.6 days and Ventilator free days $6.59 \pm 4.1$ days. The discharge SOFA $(2.37 \pm 2.2$ vs $4.21 \pm 4.2)$, admission APACHE-II $(11.17 \pm 6.5$ vs $20.14 \pm 4.0)$ and ICU $\operatorname{LOS}(2.96 \pm 2.0$ vs $4.14 \pm 3.3)$ were significantly higher in non-survivors on univariate analysis $(\mathrm{p}<0.05)$. The need for Post-operative fluid resuscitation, poor glycaemic control, presence of coagulopathy and surgical complications were also associated with higher hospital mortality $(\mathrm{p}<0.05)$.

\section{Conclusions}

Non cardiac surgical patients requiring ICU admission has significant hospital mortality.

\section{Grant Acknowledgment}

NIL.

\section{Authors' details \\ ${ }^{1}$ Sri Ramachandra Medical College and Research Institute, Dept of Critical Care Medicine, Chennai, India. ${ }^{2}$ Sri Ramachandra Medical College and Research Institute, Dept of Anaesthesiology, Chennai, India.}

\section{Published: 1 October 2015}

\section{References}

1. Rinaldo Bellomo, et al: Postoperative serious adverse events in a teaching hospital: A prospective study. MJA 2002, 176, 4 March. 
2. Suzana M: Lobo et al Early Determinants of Death Due to Multiple Organ Failure After Non-cardiac Surgery in High-Risk Patients. Anesthesia Analgesia 2011, 112:877-83.

doi:10.1186/2197-425X-3-S1-A737

Cite this article as: Pradeep Kumar et al:: Outcome of non cardiac surgical patients admitted to a multidisciplinary Indian ICU. Intensive Care Medicine Experimental 2015 3(Suppl 1):A737.

\section{Submit your manuscript to a SpringerOpen ${ }^{\mathcal{O}}$ journal and benefit from:}

- Convenient online submission

- Rigorous peer review

- Immediate publication on acceptance

- Open access: articles freely available online

- High visibility within the field

- Retaining the copyright to your article

Submit your next manuscript at $>$ springeropen.com 